Iğdır Üniversitesi Fen Bilimleri Enstitüsü Dergisi, 11(Özel Sayı): 3519-3527, 2021

Journal of the Institute of Science and Technology, 11(Special Issue): 3519-3527, 2021

Tarla Bitkileri / Field Crops

ISSN: 2146-0574, eISSN: 2536-4618

DOI: 10.21597/jist.1026820

Araştırma Makalesi / Research Article

Geliş tarihi / Received: 22.11.2021

Kabul tarihi / Accepted: 12.12.2021

Atıf İçin: Koca YO, Yalçın M, Turgut C, 2021. Tohum Kaplamasında Kullanılan Bazı Pestisitlerin Mısırın Morfolojik ve Kalite Özelliklerine Etkileri. Iğdır Üniversitesi Fen Bilimleri Enstitüsü Dergisi, 11(Özel Sayı): 3519-3527.

To Cite: Koca YO, Yalçın M, Turgut C, 2021. Effects of Some Pesticides Used Seed-Coating on Morphological and Quality Parameters of Corn. Journal of the Institute of Science and Technology, 11(Special Issue): 3519-3527.

\title{
Tohum Kaplamasında Kullanılan Bazı Pestisitlerin Mısırın Morfolojik Ve Kalite Özelliklerine Etkileri
}

\section{Yakup Onur KOCA ${ }^{1 *}$, Melis YALÇIN ${ }^{2}$, Cafer TURGUT ${ }^{2}$}

ÖZET: Bu çalışma ile metalaxy-M + fludioxonil (Maxim XL 035 FS), clothianidin (Poncho FS 600) ve cyantraniliprole (Fortenza 600 FS) etken maddeli tohum ilacı olarak kullanılan pestisitleri mısırın (Zea mays L.) verim ve kalitesi üzerine etkileri belirlenmiştir. Belirtilen pestisitlerin önerilen dozları kullanılarak Pioneer P2088 mısır çeşidinin tohumlarına kaplama işlemi gerçekleştirilmiştir. Çalışmada, mısır çeşidinin birçok morfolojik özelliklerine (tohum verimi, bitki boyu, koçan boyu, koçanda tane sayısı, koçandaki tohum ağırlığı, bin tohum ağırlığı, sap kalınlığı ve yaprak kalınlığı) ek olarak bazı tohum kalite parametreleride (kül, yağ, protein ve nişasta oranları) ölçülmüştür. Çalışmanın sonucunda, yaprak kalınlığı dışında ölçülen tüm morfolojik özelliklerde uygulamalar arasındaki farklılıkların önemsiz olduğu bulunmuştur. Buna karşın çalışmada ölçülen tüm kalite özelliklerinde uygulamalar arasındaki farklılıkların önemli olduğu tespit edilmiştir. En yüksek yaprak kalınlığ 1 (5.04 mm) ve nişasta oranı (\% 58.61) değerleri metalaxyl-M + fludioxonil uygulamasından elde edilmiştir. En yüksek kül $(\% 1.22)$ ve protein içeriği $(\%$ 8.71) kontrolden elde edilmiştir. Tohumlarda en yüksek yağ (\% 4.20) oranı clothianidin uygulamasında ölçülmüştür.

Anahtar Kelimeler: pestisitler, mısır, protein oranı, nişasta oranı, yaprak kalınlığı

\section{Effects of Some Pesticides Used as Seed-Coating on Morphological and Quality Parameters of Corn}

ABSTRACT: In this study, the effects of seed coated pesticides with active ingredients metalaxil-M + fludioxonil (Maxim XL 035 FS), clothianidin (Poncho FS 600) and cyantraniliprole (Fortenza 600 FS) on yield and quality of maize (Zea mays L.) were determined. The seeds of the Pioneer P2088 corn variety were coated using the recommended doses of the specified pesticides. In addition to many morphological features (seed yield, plant height, cob height, number of seeds on the cob, seed weight on cob, thousand seed weight, stem thickness, and leaf thickness), some seed quality parameters (ash, fat, protein and starch rates) were measured. As a result of the experiment, differences between the treatments in all morphological features except for leaf thickness were found insignificant. On the other hand, the differences were found to be significant in all the quality parameters. The highest leaf thickness $(5.04 \mathrm{~mm})$ and starch rate $(58.61 \%)$ were obtained from metalaxyl-M + fludioxonil application. The highest ash $(1.22 \%)$ and protein contents $(8.71 \%)$ were obtained from control. The highest oil $(4.20 \%)$ rate of seed was measured in clothianidin treatment.

Keywords: pesticides, corn, protein rate, starch rate, leaf thickness

\footnotetext{
${ }^{1}$ Yakup Onur KOCA (Orcid ID: 0000-0002-0753-0077), Aydın Adnan Menderes Üniversitesi, Ziraat Fakültesi, Tarla Bitkileri Bölümü, Aydın, Türkiye

${ }^{2}$ Melis YALÇIN (Orcid ID: 0000-0002-9122-7133), Cafer TURGUT (Orcid ID: 0000-0002-6450-5361) Aydin Adnan Menderes Üniversitesi, Ziraat Fakültesi, Bitki Koruma Bölümü, Aydın, Türkiye

*Sorumlu Yazar/Corresponding Author: Yakup Onur KOCA, e-mail: yokoca@adu.edu.tr

Uluslararası Katılımlı Türkiye 7. Tohumculuk Kongresi’nde” sözlü bildiri olarak sunulmuştur.
} 


\section{GíRiş}

Mısır bitkisi, Dünyanın birçok bölgesinde (tropik, subtropik ve 1lıman iklim kuşakları) yetişebilen ve neredeyse söz konusu bölgelerdeki ülkelerin tamamında belli oranlarda tarımı yapılan geniş uyum yeteneğine sahip bir bitkidir. Kutup bölgeleri hariç dünya çapında bir üretim ve yetiştiriciliğe sahiptir. $58^{\circ}$ kuzey ve $40^{\circ}$ güney enlemleri arasında kalan alanların neredeyse tamamında, deniz seviyesinden 4000 m' ye kadar olan rakımlarda yetiştirilebilmektedir (Kırtok, 1998).

Dünyada ve ülkemizde yoğun bir şekilde kullanılan mısır bitkisinin, her yıl üretimi artmaktadır. Bitkinin 2019 yılında ekim alanı dünyada 197 milyon ha ve üretimi bir milyar yüzonbeş milyon ton dur. Ülkemizde ise üretim 6 milyon ton civarında iken, tüketim 7.8 milyon tonu bulmaktadır (Anonim a, 2019). Ülkemizde tüketimi çoğunlukla hayvan yemi olarak ya da doğrudan insan beslenmesinde (mısır unu, nişasta, haşlamalık vb.) kullanılmakla beraber birçok gıda maddesinin içine de girebilmektedir (Koca, 2009). Bugün mısır ya da mısırdan elde edilen yan ürünler (şeker, zamk, yăg vb.) birçok işlenmiş gıdalarda yer alabilmekte ve enerji kaynaklarından temel gıdalara kadar birçok alanda kullanılmaktadır. Bu durum günden güne artan mısır talebini açıklamaktadır.

Konvansiyonel tarım ile geniş alanlarda üretimi yapılan mısır bitkisinin ekiminden hasadına kadar birçok aşamada farklı kültürel uygulamalar yapılmaktadır. Başlangıçta tarlada başarılı bir tohum yatağının hazırlanması ve birim alanda yeterli fide sayısının belirlenmesi, mısırın tane üretimi için en önemli ve kritik adımlardan biridir (Pereira et al., 2019). Yetiştirilen bitkilerin sağlıklı bir şekilde çıkış yapması ve sonrasında sağlıklı bir fide dönemi geçirerek gelişimlerine devam etmeleri öncelikli hedefler arasındadır (Baldini et al. 2018). Çıkış esnasında ve fide döneminde toprakta bulunabilecek birçok hastalık etmeni ve zararlılara karşı uygulamalar ekim öncesinde yapılmaktadır. Çünkü mısır bitkisini söz edilen gelişme dönemlerinde etkileyerek üretimi düşürme potansiyeline sahip birçok toprak altı ve toprak üstü hastalık etmenleri ve zararlılar bulunmaktadır.

Söz konusu hastalık etmenleri ve zararlılar; üretim, verim ve kalitede ciddi düşüşe neden olmaktadır. Ekim öncesinde uygulanan tohum kaplama ilaçları mısırda çıkış esnasında ve sonrasında sorun olabilecek önemli hastalık ve zararlılara karşı koruma sağlamıştır. Pythium spp., Fusarium spp., ve Rhizoctonia spp. gibi fungal etmenlerin mısır bitkisine olan tipik etkileri, tohumun çürümesi, çimlendiyse çıkış öncesi veya çıkış sonrası ölümler, ileriki dönemlerde gövde ekseninde kayma ve bazı ters bükülmeler sonucunda bitkinin devrilmesi şeklinde görülebilmektedir (Anonim b, 2019). Bu hastalıklar \%20-30'lara ulaşabilen verim kayıpları meydana getirebilmektedir. Misırda bozkurt (Agrotis ipsilon, Agrotis segetum) larvaları, fide dönemindeki bitkileri kök boğazından keserek fidelerin zarar görmelerine hatta ölümlerine sebep olurlar. Mısırda tel kurtları (Agriotes spp.) bitkileri toprak altı organlarına zarar verirler. İnce olan mısır köklerini zedeler bazen de koparırlar, kalın köklerde ve toprağa yakın ana gövde içinde galeriler açarak beslenirler (Anonim, 2020).

Mısır bitkisinin bu hastalık etmenlerine ve zararlılarına karşı kullanılan bazı tohum ilaçları (pestisitler) bulunmaktadır. Mısır tarımında yoğun bir şekilde pestisit kullanımı olmasına karşın bunların verim ve kaliteye etkileri göz ardı edilmektedir (Yousof et al. 2016). Tohumun ilaçlamasının erken bitki gelişimin dönemlerinde (çıkış ve fide dönemi) ciddi zararlara yol açabilecek hastalık etmenleri ve zararlılara karşı bitkiyi koruyarak birçok olumlu etkilerinin bulunduğundan söz eden yayınlar bulunmaktadır (Steffen ve ark., 1999; Wilde ve ark., 2004; Vernon ve ark., 2013). Buna karşın, söz konusu kimyasalların tohumun çimlenme gücünü etkilemenin yanında, olumsuz çevre koşulları ile birleştiğinde (tohum yatağının iyi hazırlanmaması, kesekler, ağır toprak tavı ya da alatav) mısır tohumlarının çimlenme ve sürme gücünü olumsuz yönde etkileyebildiklerini söyleyen bazı çalışmalar da bulunmaktadır (Marchi and Cicero, 2003; Hejlik, 2012). Bu çalışma ile tohum 
kaplamada kullanılan metalaxil-M + fludioxonil (Maxim XL 035 FS), clothianidin (Poncho FS 600) ve cyantraniliprole (Fortenza 600 FS) sistemik etkili ilaçların mısır üzerindeki bazı etkileri belirlenmeye çalışılmıştır.

\section{MATERYAL VE METOT}

Denemenin bitkisel materyali olarak Pioneer P2088 seçilmiştir. Bölge ekolojik koşullarına uygun yüksek verim potansiyeline sahip bir çeşit olarak nitelendirilebilir. Özellikle dik ve geniş yapraklı geniş fotosentez alanına sahip bir bitkidir. Bunun sonucunda koçanda sıra sayısı fazladır. Derin, kaliteli ve hektolitre ağırlığı yüksek taneleri bulunmaktadır. Her toprak türünde yüksek verim gücüne sahiptir. Sağlam sap yapısına sahip ve yeşil kalma yeteneği yüksektir. Hastalıklara nispi toleranslıdır (Anonim, 2021).

Türkiye'de ticari olarak satılan mısır tohumların neredeyse tamamı ilaçlı olarak satılmaktadır. Poncho ile Maxim mısırda ruhsatlı olan tohum ilaçlarıdır. Bunlara Fortenza da eklenerek oluşturulan uygulama grubunun (3 misır tohum ilacı) diğer tohum ilaçlarını da temsil etmesi sağlanmaya çalışılmıştır. Tohum kaplamada kullanılan uygulama grubundaki sistemik etkili ilaçların içerikleri ve kullanım dozları aşağıda maddeler halinde verilmiştir.

Maxim XL 035 FS $25 \mathrm{~g} \mathrm{~L}^{-1}$ fludioxonil ve $10 \mathrm{~g} \mathrm{~L}^{-1}$ metalaxyl-M içerir. Mısırda tohum ve kök çürüklüğü, Fide yanıklığına (Pythium spp. Fusarium spp. Rhizoctonia spp.) karşı kullanılmaktadır. 100 $\mathrm{kg}$ tohuma $100 \mathrm{ml}$ dozunda uygulanır. Fludioxonil E2 grubunda bulunup Phenylpyrrolleler içerisinde bulunmaktadır. Hücre metabolizmasında rol oynayan protein kinazı inhibe eder. Metalaxyl -M ise A1 grubunda bulunup Phenylamidelerden acylalanine içerisinde yer alır. RNA polimeraz enzimini engelleyerek protein sentezinin ihibasyonuna neden olur (Tomlin, 2004).

Poncho FS $600 \mathrm{~g} \mathrm{~L}^{-1}$ clothianidin içerir. Böceklerde merkezi sinir sistemindeki sinapsları etkileyerek sistemik ve translaminar etki şekline sahiptir. Nikotinik asetilkolin reseptör agonisti olarak etki eder. Etki mekanizmasına göre Grup 4A'da bulunup neonikotinoidler sınıfında yer alır. Geniş etki şekline sahiptir. Mısırda Tel kurtlarına (Agriotes spp.) ve Bozkurtlara (Agrotis ipsilon, Agrotis segetum) karşı kullanılmaktadır. $84 \mathrm{ml} \mathrm{L}^{-1}$ ünite (50000 adet tohum) dozunda uygulanır (Tomlin, 2004).

Fortenza $600 \mathrm{FS}, 600 \mathrm{~g} \mathrm{~L}^{-1}$ cyantraniliprole içerir. Grup 28'de bulunup Diamideler içerisinde yer alır. Sistemik özelliğe sahiptir. Ryanodine reseptör modülatörü olarak görev yapar. $30 \mathrm{ml} \mathrm{L}^{-1}$ ünite (50000 adet tohum) uygulama dozudur. Mısırda Bozkurtlara karşı (Agrotis segetum, Agrotis ipsilon) kullanılir.

\section{Yöntem}

Araştırmanın tarla çalışması 2019 yılında Aydın Adnan Menderes Üniversitesi Ziraat Fakültesi Tarla Bitkileri uygulama alanında yürütülmüştür. Tohumların ekimi öncesinde deneme materyali olarak Pioneer firmasından kaplamasız olarak (ilaçsız), P2088 tane mısır çeşidi alınmış (1 çuval = 50000 adet) ve yaklaşık 4 eşit (g olarak) parçaya (kontrol dahil) ayırılmıştır. Daha sonrasında sistemik etkili 3 farklı ilacın tohumlara kaplanması yukarıda belirtilen ilaç dozlarına uygun olarak film kaplama yöntemi ile yaptırılmıştır. Buna ek olarak hiçbir ilacın kaplanmadığı tohumlar kontrol parsellerinde kullanılmıştır.

Çizelge 1'de denemenin kurulduğu alanın toprak analiz sonuçları verilmiştir. Buna göre deneme alanının toprak yapısı kumlu-tınlı, alkali karakterli ve organik maddesi düşük olduğu söylenebilir. 
Çizelge 1. Toprak analiz sonuçları

\begin{tabular}{|c|c|c|c|c|c|c|}
\hline \multicolumn{3}{|c|}{ Toprak tekstürü (\%) } & pH & Organik madde (\%) & $\mathbf{P}(\mathbf{p p m})$ & $\mathrm{K}(\mathbf{p p m})$ \\
\hline Kum & Mil & Kil & & & & \\
\hline 72 & $\begin{array}{c}16.7 \\
\text { Kumlu tinl }\end{array}$ & 11.3 & $\begin{array}{c}8.0 \\
\text { yüksek }\end{array}$ & $\begin{array}{c}1.91 \\
\text { düşük }\end{array}$ & $\begin{array}{c}21 \\
\text { yüksek }\end{array}$ & $\begin{array}{c}176 \\
\text { düşük }\end{array}$ \\
\hline
\end{tabular}

Çalışmanın yürütüldüğü yıla ait aylık ortalama sıcaklık ve aylık yağış oranı değerleri ile uzun yıllar ortalaması Çizelge 2 de verilmiştir. Meteoroloji verileri incelendiğinde denemenin yürütüldüğü yıl olan 2019 yılında haziran ayı yağış değerinin çok yüksek olduğu görülmektedir. Buna ek olarak 2019 yılı birinci ürün mısır üretim dönemi boyunca (Nisan-Eylül) etkili aylık ortalama sıcaklık değerlerinin de uzun yılların ortalamasından ya düşük ya da çok yakın değerler olduğu (Mayıs hariç) görülmektedir. 2019 yılı için serin ve yağışlı bir üretim dönemine sahip olduğu söylenebilir.

Ana ürün tane mısır yetiştiriciliği koşullarında farklı ilaç uygulamasının içinde bulunduğu 4 farklı uygulamayı (kontrol dahil) kapsayan tarla çalışması tesadüf blokları deneme desenine göre 3 tekerrürlü olarak kurulmuştur. 27.04.2019 tarihinde denemede sıra arası mesafe $70 \mathrm{~cm}$ sira üzeri mesafe $20 \mathrm{~cm}$ olarak 12 metre uzunluğunda sıraların (4 sira) bulunduğu parseller şeklinde ekim gerçekleştirilmiştir. Mısır üretim dönemi boyunca konvansiyonel tarım uygulamasına göre standart kültürel işlemler uygulanmıştır.

Çalışmada birçok morfolojik özellikler (tohum verimi, bitki boyu, koçan boyu, koçandaki tohum sayısı, koçandaki tohum ağırlığı, bin tohum ağırlığı, sap kalınlığ1 ve yaprak kalınlığı) tahta cetvel, elektronik kumpas, nemölçer ve elektronik tartı gibi bazı aletler ile ölçülmüştür. Buna ek olarak bazı tane kalite özellikleri de belirlenmeye çalışılmıştır. Tane kalitesi özellikleri [tanede protein (\%), nişasta (\%), yăg (\%) ve kül (\%)] elde edilen tanelerin Adnan Menderes Üniversitesi Tarımsal Biyoteknoloji Merkezi Laboratuvarındaki NIRS (Near Infrared Reflectance Spectroscopy) cihazında ölçülmesi ile saptanmıştır. $\mathrm{Bu}$ analiz, mısır denemelerinden alınan yaklaşık $90 \mathrm{~g}$ mısır taneleri ile $2.8 \mathrm{~cm}$ derinliğinde ve $9 \mathrm{~cm}$ çapında numune kaplarında taneler öğütülerek ölçüm yapılmıştır (Gislum ve ark., 2004).

Çizelge 2. 2019 yılı ve uzun yıllara ait meteoroloji verileri

\begin{tabular}{ccccc}
\hline \multirow{2}{*}{ Aylar } & \multicolumn{2}{c}{ Sicaklık $\left({ }^{\circ} \mathrm{C}\right)$} & 2019 & Yağış $(\mathrm{mm})$ \\
& 2019 & Uzun yıllar & 59.2 & 45.5 \\
Nisan & 15.8 & 15.7 & 8.3 & 33.5 \\
Mayıs & 22.4 & 20.9 & 97.7 & 14.0 \\
Haziran & 25.6 & 25.9 & 0.2 & 3.5 \\
Temmuz & 26.6 & 28.4 & 0.0 & 2.2 \\
Ağustos & 27.2 & 27.2 & 11.8 & 14.4 \\
Eylül & 22.1 & 23.2 & & \\
\hline
\end{tabular}

\section{İstatistiksel Analizler}

İstatistiksel analizler; çalışmadan elde edilen değerlerin varyans analizi yapılarak değerlendirilmesi ve ortalamalar arasındaki farklılıkların En Küçük Önemli Fark (EKÖF) çoklu karşılaştırma testi ile karşılaştırılması ile sonuçlandırılmıştır. Bunun için Tarist paket programı kullanılarak yapılmıştır (Açıkgöz ve ark., 2004).

\section{BULGULAR VE TARTIŞMA}

Varyans analiz sonucunda farklı ilaç uygulamalarından elde edilen değerlere ait kareler ortalaması değerleri ve uygulamalar arasındaki farkların önem düzeylerini belirten sonuçlar Çizelge 3'de verilmiştir. Buna göre ölçülen morfolojik özelliklerin (tohum verimi, bin tane ağırlığ 1 , koçan 
boyu, koçanda tane sayısı, bitki boyu, koçanda tane ağırlığı ve sap kalınlığı) tamamında (yaprak kalınlığı hariç) uygulamalardan oluşan farkların önemsiz olduğu görülmektedir. Buna karşın tane kalitesi ile ilgili ölçülen özelliklerin (tanede kül oranı, tanede protein oranı, tanede nişasta oranı ve tanede yağ oranı) tamamında uygulamadan oluşan farklılık önemli bulunmuştur.

Çizelge 3. Varyans analizi sonucunda özelliklerden elde edilen kareler ortalaması değerleri

\begin{tabular}{|c|c|c|c|c|c|c|c|c|c|c|c|c|}
\hline \multirow{2}{*}{ VK } & \multirow{2}{*}{ TV } & \multirow{2}{*}{ BTA } & \multirow{2}{*}{ KB } & \multirow{2}{*}{ KTS } & \multirow{2}{*}{ BB } & \multirow{2}{*}{ KTA } & \multirow{2}{*}{ SK } & \multirow{2}{*}{ YK } & \multicolumn{4}{|c|}{ Tanede } \\
\hline & & & & & & & & & Kül & Pro & Niş & Yă̆ \\
\hline Uygulama & 66572.7öd & 686.8öd & 0.9 öd & 13177.7öd & 463.2öd & 1305.2öd & 9.3öd & $2.4^{*}$ & $0.0^{*}$ & $0.3^{* *}$ & $4.5 * *$ & $0.0^{*}$ \\
\hline Hata & 172864.9 & 601.5 & 5.2 & 14946.5 & 152.8 & 3388.9 & 2.8 & 0.5 & 0.0 & 0.0 & 0.0 & 0.0 \\
\hline
\end{tabular}

öd: önemli değil, *: 0.05 düzeyinde önemli, **: 0.01 düzeyinde önemli

VK: Varyasyon Kaynağı TV: Tohum verimi, BTA: Bin tane ağırlı̆̆ı KB: Koçan boyu, KTS: Koçanda tane sayısı, BB: Bitki boyu, KTA: Koçanda tane ağırlığı, GK: Sap kalınlığı, YK: Yaprak kalınlığı, Kül: Tanede kül oranı, Pro: Tanede protein oranı, Niş: Tanede nişasta oranı, Yağ: Tanede yağ oranı

\section{Bitki Boyu (cm)}

Tahıllarda bitki boyu geniş ölçüde genetik faktörlerin etkisi altında olan bir özelliktir. Buna ek olarak bu özellik çevresel faktörlerden de (1şık miktarı, bitki besin maddesi ve sulama vb.) geniş ölçüde etkilenmektedir (Hallauer ve Miranda, 1982).

Denemede kullanılan ilaç çeşitlerinin bitki boyuna olan etkileri değerlendirildiğinde en uzun bitki boyu ortalaması $(268.33 \mathrm{~cm}$ ) Maxim-XL 035 FS ilaç uygulamasında olmuştur (Çizelge 4). Bunu $(248.33 \mathrm{~cm})$ değeri ile Poncho FS 600 ilacı izlemiştir. En düşük değer ise $(240.00 \mathrm{~cm})$ ile ilaç uygulanmayan (kontrol) parselden ölçülmüştür.

\section{Koçan Boyu (cm)}

Bitkilerin birçok tarımsal özellikleri (boy, yaprak alanı, birim alandaki sıklık, biyolojik verim, hasat indeksi, koçanın yüksekliği, boyu, kalınlığı ile koçanda tane sayısı ve bin tane ağırlığı) tane verim öğeleri arasındadır (Xu, 1986; Jatimliansky ve ark., 1986; Cesurer ve ark, 1999). Fakat bunların arasında genellikle ters bir korelasyonun bulunduğu bilinmektedir. Bu sebeple mısırda yüksek tane veriminin iyi dengelenmiş verim öğeleri ile oluşturulabileceği vurgulanmıştır (Gay ve Black 1984).

Denemede kullanılan ilaç çeşitlerinin koçan boyuna olan etkileri değerlendirildiğinde en uzun koçan boyu $(20.77 \mathrm{~cm}$ ) Fortenza 600 FS ilaç uygulamasından ölçülmüştür (Çizelge 4). Bunu $20.13 \mathrm{~cm}$ değeri ile Poncho FS 600 ilacı izlemiştir. En düşük değer ise $(19.57 \mathrm{~cm})$ ile kontrol parselinden ölçülmüştür.

\section{Koçanda Tane Sayısı (adet)}

Tahıllarda genel olarak verim öğeleri içerisinde en önemlileri birim alandaki tane miktarı ve bunun ağırlı̆̆ıdır (Tollenear ve ark. 1992; Kara 2001). Tane verimini direk etkilemesi bakımından yapılan çalışmalarda koçanda tane sayısı ve bin tane ağırlığı değerleri öncelikli önem taşımaktadır ve birincil (primer) tane verim öğeleri olarak adlandırılabilir (Singh ve ark., 1982).

Denemede kullanılan farklı ilaçların koçanda tane sayısına olan etkileri değerlendirildiğinde en yüksek koçanda tane sayısı (678.4) Fortenza 600 FS uygulanmış parselden elde edildi (Çizelge 4). Bunu 620.4 adet ortalama ile Poncho FS 600 ilacı izlemiştir. En düşük değer ise (524.1) ile ilaç uygulanmayan parselden ölçülmüştür.

\section{Bin Tane Ağırlığı (g)}

Denemede kullanılan ilaç çeşitlerinin bin tane ağırlığına olan etkileri değerlendirildiğinde en yüksek bin tane ağırlığı (429.5 g) ortalaması kontrol parselinden ölçüldü. Bunu $405.7 \mathrm{~g}$ değeri ile Poncho FS 600 parseli izlemiştir. En düşük değer ise (396.6 g) Fortenza 600 FS parselinden ölçülmüştür. 


\section{Koçanda Tane Ağırlı̆̆ı (g)}

Dekarda tane veriminin önemli belirleyicilerinden olan tek koçanda tane ağırlığı değerlerini incelediğimizde; en yüksek koçanda tane ağırlığı (269.1 g) ölçülen ilaç uygulama parseli Fortenza 600 FS de olmuştur (Çizelge 4). Bunu 253.4 g değeri ile Poncho FS 600 izlemiştir. En düşük değer ise $(225.1 \mathrm{~g})$ ile ilaç uygulanmayan parselden ölçülmüştür.

\section{Tane Verimi $\left(\mathrm{kg} \mathrm{da}^{-1}\right)$}

Çalışmadan bölge koşullarında yüksek sayılabilecek tane verimi değerleri elde edilmesine rağmen ilaç uygulamalarından elde edilen tane verimi sonuçları arasında verim öğelerine paralel bir şekilde istatistiki olarak bir fark olmadığı görülmüştür. Denemede kullanılan ilaç çeşitlerinin dekara tane verimine olan etkileri değerlendirildiğinde en yüksek tane verimi (1922 kg da-1) ortalaması Fortenza 600 FS uygulanan parsellerden elde edilmiştir (Çizelge 4). Bunu $1810 \mathrm{~kg} \mathrm{da}^{-1}$ değeri ile Poncho FS 600 parseli izlemiştir. En düşük değer ise $\left(1608 \mathrm{~kg} \mathrm{da}^{-1}\right)$ ile kontrol parselinden ölçülmüştür.

Çizelge 2'de verilen meteoroloji değerleri incelendiğinde 2019 yılı nisan ve mayıs aylarının uzun yıllar ortalamasından daha sıcak geçtiği söylenebilir. Bu dönemde hava sıcaklığına bağlı olarak hızla artan toprak sıcaklığg nisan ayı sonunda (27.04.2019) ekimi yapılan mısır tohumlarının hızlı bir çıkış göstermesine yardımcı olmuştur. Devam eden süreçte sıcaklığın korunması bitkilerin daha sağlıklı bir fide dönemi geçirmesini sağlamıştır. Buna ek olarak haziran ayında uzun yıllar ortalamasının çok üzerinde bir yağış oranı olması bitki büyümesini desteklemektedir. Mısır bitkisinin iki önemli isteği olan sıcaklık ve su doğal olarak karşılanmıştır. Haziran ve temmuz aylarında uzun yıllar ortalamasından daha düşük sıcaklıklar ölçülmesi bitkilerin yüksek sıcaklık stresine girmesini de engellemiştir. Bu sebeple çalışmada ölçülen en düşük tane verimi ortalaması (1608 kg da-1) bile bölge koşullarına göre (damlama sulama ile üretim hariç) biraz yüksek olarak görülebilir. Çalışmadan elde edilen en yüksek tane verimi ortalaması ise neredeyse iki tona yaklaşmıştır. Üretim yapılan yılın mısır bitkisi yetiştirmeye çok uygun koşulları sağlaması elde edilen değerleri birbirine yaklaştırmış olabilir. $\mathrm{Bu}$ sebeple, uygulamalar arasındaki farklar belirgin olarak ortaya çıkmamıştır. Genel olarak ilaç uygulamalarından elde edilen dekara tane verimi ve verim öğeleri arasında istatistiki olarak farklılık gözlenememiştir. Buna rağmen, kontrol uygulamasına göre Fortenza parsellerinde tane verim neredeyse $\% 20$ ye yakın artı̧ göstermiştir.

Çizelge 4. Pestisit uygulamalarından elde edilen morfolojik özelliklere ait ortalamalar

\begin{tabular}{|c|c|c|c|c|c|c|c|c|}
\hline Uygulamalar & TV $\left(\mathrm{kg} \mathrm{da}^{-1}\right)$ & BTA $(\mathbf{g})$ & $\mathrm{KB}(\mathbf{c m})$ & KTS & $\mathrm{BB}(\mathrm{cm})$ & KTA (g) & SK (mm) & YK $(\mathbf{m m})$ \\
\hline Kontrol & 1607.9 & 429.5 & 19.6 & 524.1 & 240.0 & 225.1 & 17.6 & 5.4 \\
\hline $\begin{array}{c}\text { Maxim-XL } 035 \\
\text { FS }\end{array}$ & 1634.0 & 398.6 & 19.7 & 571.9 & 268.3 & 228.8 & 18.5 & 7.1 \\
\hline Poncho FS 600 & 1810.0 & 405.7 & 20.1 & 620.4 & 248.3 & 253.4 & 15.7 & 5.0 \\
\hline Fortenza $600 \mathrm{FS}$ & 1922.0 & 396.6 & 20.8 & 678.4 & 245.0 & 269.1 & 20.0 & 6.0 \\
\hline EKÖF & - & - & - & - & - & - & - & 1.4 \\
\hline
\end{tabular}

\section{Sap Kalınlığı (mm)}

Denemede kullanılan ilaç çeşitlerinin sap kalınlığına olan etkileri değerlendirildiğinde en fazla sap kalınlığı (20.0 mm) ölçülen ilaç uygulama parseli Fortenza 600 FS de olmuştur. Bunu (18.5 mm) değeri ile Maxim-XL 035 FS ilacı izlemiştir. En düşük değer ise $(15.7 \mathrm{~mm})$ ile Poncho FS600 parselinden ölçülmüştür. 


\section{Yaprak Kalınlı̆̆ı (mm)}

Bitkilerin yüksek düzeyde fotosentez yapan en önemli organı olan yapraklarda (Kara ve Akman 2002) kullanılan ilaçlar sonucunda istatistiki olarak önemli farklılıklarda yaprak kalınlığı değerleri elde edilmiştir. Denemede kullanılan ilaç çeşitlerinin yaprak kalınlığına olan etkileri değerlendirildiğinde en fazla yaprak kalınlığı $(7.1 \mathrm{~mm})$ ölçülen ilaç uygulama parseli Maxim-XL 035 FS de olmuştur. Bunu $(6.0 \mathrm{~mm})$ değeri ile Fortenza 600 FS ilacı izlemiştir. En düşük değer ise $(5.0 \mathrm{~mm})$ ile Poncho FS600 parselinden ölçülmüştür.

\section{Tanede Kül Oranı (\%)}

Denemede kullanılan ilaç çeşitlerinin tanede kül oranına olan etkileri değerlendirildiğinde en fazla kül oranı (\%1.2) ölçülen kontrol parselinde olmuştur (Çizelge 5). Bunu (\%1.2) değeri ile Poncho FS600 ilacı izlemiştir. En düşük değer ise (\%1.2) ile Maxim-XL 035 FS parselinden ölçülmüştür.

\section{Tanede Yağ Oranı (\%)}

Denemede kullanılan ilaç çeşitlerinin tanede yă̆ oranına olan etkileri değerlendirildiğinde en fazla yağ oranı (\%4.2) ölçülen Poncho FS 600 parselinde olmuştur (Çizelge 5). Bunu (\%4.2) değeri ile kontrol parseli izlemiştir. En düşük değer ise (\%4.0) ile Maxim-XL 035 FS parselinden ölçülmüştür.

\section{Tanede Protein Oranı (\%)}

Denemede kullanılan ilaç çeşitlerinin tanede protein oranına olan etkileri değerlendirildiğinde en fazla protein oranı (\%8.7) ölçülen kontrol parseli olmuştur. Bunu Fortenza 600 FS parseli (\%8.5) izlemiştir. En düşük değer ise (\%8.0) Maxim-XL 035 FS uygulamasının yapıldığı parselden ölçülmüştür.

Çizelge 5. Pestisit uygulamalarından elde edilen kalite parametrelerine ait ortalamalar

\begin{tabular}{ccccc}
\hline \multirow{2}{*}{ Uygulamalar } & Kül & Pro & Tanede (\%) & Niş \\
\hline Kontrol & 1.22 & 8.71 & 55.85 & Yağ \\
\hline Maxim-XL 035 FS & 1.15 & 7.98 & 58.61 & 4.18 \\
Poncho FS 600 & 1.21 & 8.45 & 56.48 & 4.01 \\
Fortenza 600 FS & 1.17 & 8.46 & 57.65 & 4.20 \\
EKÖF & $\mathbf{0 . 1}$ & $\mathbf{0 . 2}$ & $\mathbf{0 . 4}$ & 4.12 \\
\hline
\end{tabular}

Kül: Tanede kül oranı, Pro: Tanede protein oranı, Niş: Tanede nişasta oranı, Yağ: Tanede yağ oranı

\section{Tanede Nişasta Oranı (\%)}

Denemede kullanılan ilaç çeşitlerinin tanede nişasta oranına olan etkileri değerlendirildiğinde en fazla nişasta oranı (\%58.6) ölçülen Maxim-XL 035 FS parselinde olmuştur. Bunu Fortenza 600 FS (\%57.7) parseli izlemiştir. En düşük değer ise (\%55.9) ile kontrol parselinden ölçülmüştür.

Tane kalite değerlerinin birbirlerine olan negatif etkileri (biri yükselirken diğerinin düşmesi) bilinen bir bulgudur (Grombacher, 1992; Kahraman ve ark., 2017). Kontrol parselinden en yüksek kül ve protein oranı değerleri ile en düşük nişasta oranı değeri ölçülmüştür. Benzer şekilde Maxim-XL 035 FS parselinden en yüksek nişasta oranı ve en düşük protein ve yağ oranı değerleri ölçülmüştür. Çalışmamızdan elde edilen değerler önceki çalışmalarda belirtilen negatif interaksiyon açısından benzer niteliktedir. Tane kalite değerleri genel olarak incelendiğinde uygulama farklılıklarının belirgin olarak ortaya çıktığ 1 gözlemlenmiştir. Buna ek olarak dekardan elde edilen tane verimi değerlerindeki değişimler de göz önüne alındığında yeni hesaplamalar ile dekardan toplam protein, toplam nişasta ve toplam yă̆ gibi değerler hesaplanabilir. İlaç uygulamaları ile ilgili daha da net sonuçlar ortaya konulabilir. 


\section{SONUÇ}

Farklı sistemik ilaçlar ile kaplanan mısır tohumlarının yetiştirilmesini inceleyen çalışmadan elde edilen sonuçlar maddeler halinde verilmiştir.

- İstatistiki değerlendirme sonucunda ölçülen morfolojik özelliklerin hiçbirinde farklılıklar önemli çıkmasa da tohum verimi, koçan boyu, bitki boyu, koçanda tane ağırlığı ve koçanda tane sayısı özelliklerinde kaplanan ilaçların olumlu etkisi olduğu gözlenmiştir. İlaç uygulamalarının tamamında bu özellikler kontrol parsellerinden ölçülen değerlerden yüksek çıkmıştır.

- İlaç uygulamalarının yaprak kalınlığına belirgin bir biçimde etkili olduğu saptanmıştır. Gelecek yıllarda yapılabilecek çalışmalarda yaprak yapısı ile ilgili bazı anatomik ve fizyolojik özelliklerin (parankima uzunluğu, stoma boyutu, epidermis kalınlığı vb.) ölçülmesi uygun olacaktır.

- İlaç uygulamalarının tane kalite özelliklerine (kül, yağ, protein ve nişasta oranları) belirgin bir biçimde etkili olduğu saptanmıştır. Gelecek yıllarda yapılabilecek çalışmalarda bu özelliklerin daha derinlemesine incelenerek (amino asit veya yağ asitleri dağılımları, çözünür şeker oranı vb.) daha net sonuçlara ulaşılması sağlanabilir.

Çalışmamız tohum kaplamada kullanılan sistemik etkili ilaçların mısır bitkisine etkileri bakımından fikir verici bir nitelikte olmuştur. Fakat daha net sonuçlar için farklı lokasyonlarda ve daha farklı özelliklerin ölçülmesiyle yapılabilecek yeni çalışmalar daha net sonuçlar elde edilmesi açısından uygun olacaktır.

\section{Çıkar Çatışması}

Makale yazarları aralarında herhangi bir çıkar çatışması olmadığını beyan ederler.

\section{Yazar Katkısı}

Yazarlar makaleye eşit oranda katkı sağlamış olduklarını beyan eder.

\section{KAYNAKLAR}

Acikgoz N, Ilker E, Gokcol A, 2004. Assessment of Biological Research on The Computer. ISBN: 973-483607-8 Ege University Seed Technology Center, Publication No: 2 Bornova-Izmir, Turkey (in Turkish).

Anonim a, 2019. FAO verileri. Erişim: https://www.fao.org/faostat/en/\#data/QCL (01.11.2021).

Anonim b, 2019. Tarım ve Orman Bakanlığı Kasım Mısır Bülteni. Erişim: https://www.Tarimorman.gov.tr /BUGEM/Belgeler/M\%C4\%B0LL\%C4\%B0\%20TA\%20KASIM\%20B\%C3\%9CLTEN\%C4\%B0.pdf (13.01.2020).

Anonim, 2020. Tarım ve Orman Bakanlığı dokümanları. Erişim: https://www.tarimorman.gov.tr /GKGM/Belgeler/Uretici_Bilgi_Kosesi/Dokumanlar/misir.pdf (13.01.2020).

Anonim, 2021. Pioneer firmasının ticari ürün kataloğu. Erişim: https://www.pioneer.com/tr/urunler/misir/ p2088.html (10.12.2021).

Baldini M, Ferfuia C, Pasquini S, 2018. Effects of Some Chemical Treatments on Standard Germination, Field Emergence and Vigour in Hybrid Maize Seeds. Seed Science and Technology, 46: 41-51.

Cesurer L, Akkaya A, Çiçek A, Yürürdurmaz C, Demirbağ V, 1999. Ikinci Ürün Bazı Hibrid Mısır Çeşitlerinde Verim ve Verim Unsurları Arasındaki Ilişkilerin Belirlenmesi. Orta Anadolu'da Hububat Tarımının Sorunları ve Çözüm Yolları Sempozyumu, 8-11 Haziran 1999, Konya, 640-644.

Gay JP, Blac D, 1984. Control of The Components of Grain Yield. Physiologie Dumais. Collaque Organise for I'INRALE CNRS ET I'ACPM. Rayon, 15 - 17 march 1983, 181 - 192.

Gislum R, Micklander E, Nielsen JP, 2004. Quantification of Nitrogen Concentration in Perennial Rye Grass and Red Fescueusing Near - İnfrared Reflectance Spectroscopy (NIRS) and Chemometrics. Field Crops Research, 88: 269- 277.

Grombacher AW, 1992. Genotype and Environment Effects on Quality Characteristics of Hard Red Winter Wheat. Crop Science 32(1): 98-103. 
Hallauer AR, Miranda JB, 1982. Quantitative Genetics in Maize Breeding. Ames: Iowa State University Press. Hejlik CC, 2012. The Assessment of Non-Pathogenic Related Effects of The Seed Treatment Stamina on Germinating Maize under Cold Stress, PhD thesis, Graduate Theses and Dissertations. Paper 12851, Iowa State University, IA, USA.

Jatimliansky JR, Urrula MI, Arturi MJ, 1986. Relationships Between Photosynthesis, Canopy Traits and Yield in Flint Type Maize. Maize Genetics Cooperation Newsletter, 62 - 73.

Jin J, Sawai K, Hashizume T, 2013. Effects of Photoperiod on Secretory Patterns of Growth Hormone in Adult Male Goats. Animal Science Journal, 84: 790-797.

Kahraman T, Öztürk İ, Avcı R, Aktaş H, 2017. Genotip X Çevre Interaksiyonunun Ekmeklik Buğdayda (T. aestivum L.) Bazı Kalite Özellikleri Üzerine Etkisi. Tarla Bitkileri Merkez Araştırma Enstitüsü Dergisi 26 (Özel Say1): 15-22.

Kara B, Akman Z, 2002. Şeker Misirinda (Zea mays saccharata sturt.) Koltuk ve Uç Alma ile Yaprak Sıyırmanın Verim ve Koçan Özelliklerine Etkisi. Akdeniz Üniversitesi Ziraat Fakültesi Dergisi, 15(2), 918.

Kara M, 2001. Bir Melez Misir Populasyonunda Verim ve Verim Unsurlari Arasindaki Ilişkilerin Korelasyon ve Path Analizi Yoluyla Değerlendirilmesi. A.Ü. Ziraat Fakültesi Yayınları, Tarım Bilimleri Dergisi, 7, (4), 1-4, Ankara.

Kırtok Y, 1998. Mısır Üretim ve Kullanımı. Kocaoluk Basın ve Yayınevi, Sayfa 445, İstanbul.

Koca YO, 2009. Aydın Bölgesinde Birinci ve İkinci Ürün Misırda (Zea mays) Verim, Verim Öğeleri, Fizyolojik ve Diğer Bazı Özellikler Arasındaki Farklılıklar. Adnan Menderes Üniversitesi Fen Bilimleri Enstitüsü Doktora Tezi. $80 \mathrm{~S}$.

Marchi JL, Cicero SM, 2003. Influence of Chemical Treatment of Maize Seeds with Different Levels of Mechanical Damage on Electrical Conductivity Value. Seed Science and Technology, 31, 481-486.

Pereira LC, Correia LV, Felber PH, Pereira RC, Matera TC, dos Santos RF, Braccini AL, 2019. Correlation Between Physiological Tests And Field Emergence In Treated Corn Seeds. Plant, Soil and Environment, 65, 569-573.

Singh R, Jashi BS, Singh S, 1982. Correlation Studies in Cowpea (Vigna unguiculata (L.) walp). Tropical Grain Legume Bull. 26: 3-5.

Steffen R, Wolff R, Iltis R, Albers M, Becker DS, 1999. Effect of Two Seed Treatment Coatings on Corn Planter Seeding Rate and Monitor Accuracy. Appl. Eng. Agric. 15: 605-608.

Tollenear M, Dwyer LM, Stewart DW, 1992. Ear and Kernel Formation in Maize Hybrids Respresting Three Decades of Grain Yield. Improvement In Ontorio. Crop Science, 32: (2), 432 - 438.

Tomlin C, 2004. The Pesticide Manual, BCPC Publications, Alton, Hampshire, UK, 1349pp.

Vernon R, Herk W, Clodius M, Harding C, 2013. Crop Protection and Mortality of Agriotes Obscurus Wireworms with Blended Insecticidal Wheat Seed Treatments. J. Pest Sci. 86: 137-150.

Wilde G, Roozeboom K, Claassen M, Janssen K, Witt M, 2004. Seed Treatment for Control of Early-Season Pest of Corn and Its Effet on Yield. J. Agric. Urban Entomol. 21: 75-85.

$\mathrm{Xu} \mathrm{ZB}, 1986$. Influence Major Characters of Maize on The Productivity of Indivudial Plants. Ningxia Agricaltural Science and Technology, 5: $26-27$.

Yousof FI, Ibrahim AEA, Abo El-Dahab MS, 2016. Efficiency of Some Seed Vigor Tests for Field Emergence Prediction of Onion Seed. Journal of Plant Production, 7: 1173-1178. 